\title{
Production and Characterization of Mechanical Properties of Sago Pulp Composite Board
}

\author{
Mitra Rahayu ${ }^{1}$, Jeffri Parrangan ${ }^{2}$, Syamsul Bahri ${ }^{3}$, \\ Helga Charolina Antonia Silubun ${ }^{4}$ \\ Physics Education Department \\ Universitas Musamus \\ Merauke, Indonesia \\ 1rahayu.mitra23@gmail.com, 2jeffri7pr@gmail.com, \\ ${ }^{3}$ syamsul_fkip@unmus.ac.id, ${ }^{4}$ helga@ unmus.ac.id
}

\author{
Dina Limbong Pamuttu ${ }^{5}$ \\ Civil Engineering Department \\ Musamus University \\ Merauke, Indonesia \\ 5dinalimbong@unmus.ac.id
}

\begin{abstract}
A study was performed on the production of sago pulp composite board and characterization of its mechanical property, i.e. tensile strength test. Sago pulp composite board was made using resin epoxy amplifier. A sago tree can produce 75 85\% sago pulp which contains $65.7 \%$ starch, $21 \%$ lignin, and $20 \%$ cellulose. The concentrations of resin epoxy used here were $9 \%, 13 \%, 17 \%, 20 \%$ and $23 \%$ with 320 gram sago pulp. The quality of the mechanical property of the composite board was examined by tensile test which showed that the ultimate strength of sago pulp composite board was quite high.
\end{abstract}

Keywords; composite; sago pulp; mechanical property

\section{INTRODUCTION}

Sago is the staple food of the people of Papua. However, today, the pulp remain from sago starch collection is unused. Usually, sago pulp is disposed or burnt. Discarded sago pulp can cause environmental pollution because sago pulp doesn't decompose easily. It's because sago pulp is lignocellulosic, in which lignocellulose consists of cellulose, hemicellulose and lignin. Cellulose is the main component of cell wall in wood. Cellulose fiber in wood is bound in lignin and complex polymer. Lignin is the main component of plant cell, so lignin affects plant characteristic. Lignin is water-resistant, so cell wall can't be penetrated by water. Moreover, lignin is resistant to microorganism growth and can store more solar energy than cellulose and hemicellulose. Lignocellulose component has similar property as wood [1], so sago pulp can be used to make composite board.

Demands for wood as construction material, whether for construction, decoration or furniture, continues to increase along with increased population. Wood demand to wood industry is around 70 million $\mathrm{m}^{3}$ per year with average increase of $14.2 \%$ per year. Waste for product processing is waste which can be processed into new material or product which has economic value. Processing waste into product must implement the principles of : reduce (reducing wood usage to reduce illegal logging), reuse, recycle, reduce cost, energy saving and efficient. An alternative solution is reprocessing unused waste into product which has selling value with applicative and popular technology, thus gaining result which is easy to socialize to the public and can be applied to conserve natural resources, especially wood material[2]
Sago is a monocot plant from family Palmae, genus Metroxylon and order Arecales. Sago can proliferate generatively (using seed which falls from sago tree) and vegetatively (using shoot attached to sago tree base). Sago can grow in marsh area or around river with $2000-4000 \mathrm{~mm}$ annual rainfall spread evenly all year and average temperature of $24^{\circ} \mathrm{C}$ to $30^{\circ} \mathrm{C}$. Sago requires sufficient water for its growth. Sago trees grow in a cluster of 1-8 sago [1]. Sago can be harvested when the tree is 6-7 years, or when the tip of the tree swells, followed by the emergence of flower bud and leaf midrib which is white, especially on the outer part. The height of sago tree is usually $10-15 \mathrm{~m}$, the diameter $60-70 \mathrm{~cm}$, the thickness of the outer bark $\pm 10 \mathrm{~cm}$ and the thickness of trunk which contains sago starch $50-60 \mathrm{~cm}$.

Sago pulp is the remains of sago tree extraction. Another extraction result is sago starch which is used for food material. One sago tree can produce $75-85 \%$ sago pulp, while the remaining $17-25 \%$ is sago starch. The chemical composition of sago pulp is: water $(12.2 \%)$, raw protein $(3.3 \%)$, fat $(0.3 \%)$, raw fiber $(14.0 \%)$, ash/inorganic residual of combustion process $(5.0 \%)$ and extract material without nitrogen $(84.6 \%)$

Composite is a material system which consists of mixture or combination of two or more material compositions which don't dissolve each other [3]. The constituent elements of a composite are matrix and amplifier. The dominant part which takes up composite is called matrix, while the non-dominant part is amplifier. Composite is a hybrid material consisting of polymer resin reinforced by combining mechanical and physical properties. Composite board has some advantages compared with real wood, i.e. composite board is free from wood knot, breaking and cracking. The size and density of composite board also can be adjusted as required. It's isotropic and its properties and quality are adjustable. The disadvantage of composite board is low dimension stability. The expansion of the width of composite board is $10 \%$ to $25 \%$ from dry to wet condition, exceeding the expansion of whole wood. The linear expansion is up to $0.35 \%$. The expansion of length and width greatly affects composite board, especially if used as construction material [4] 


\section{RESEARCH METHOD}

The samples for testing composite board consisted of 5 different adhesive ratios with the same sago pulp mass of 320 gram. Sago pulp which would be used must be sun dried first, to prevent reduction of sago pulp mass. The raw fiber of sago pulp was cut with $\pm 0,8 \mathrm{~cm}$ length.

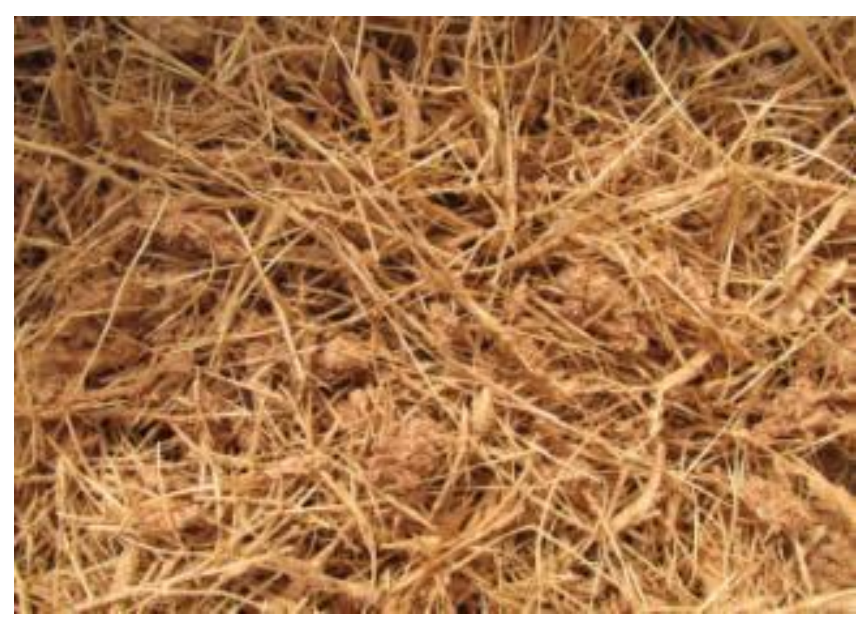

Fig. 1. Raw Fiber of Sago pulp

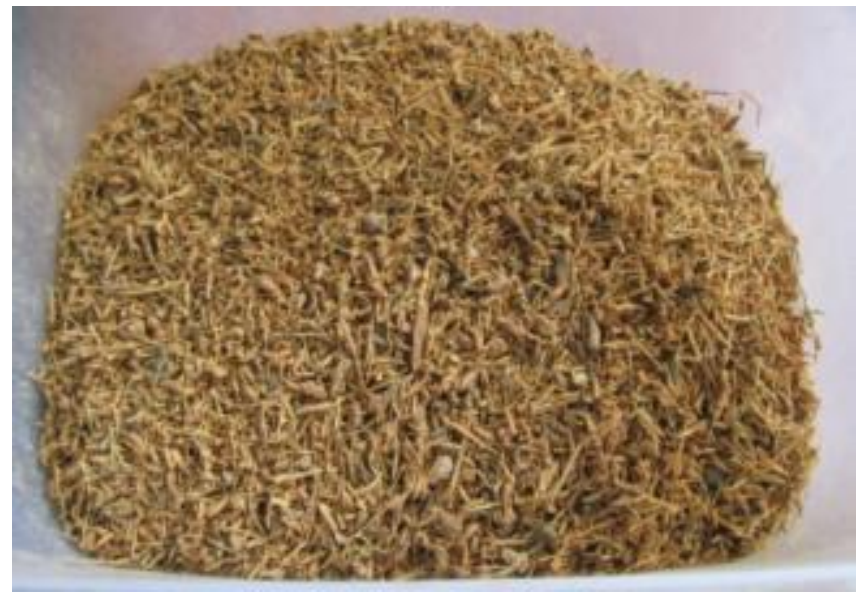

Fig. 2. Raw Fiber of Sago pulp has been cut

The ratios of epoxy resin adhesives used here were:

1. Sample 1 used $10 \%$ adhesive mass with the ratio of 16 gram epoxy resin to 16 gram epoxy hardener, so the adhesive concentration was $9 \%$.

2. Sample 2 used $15 \%$ adhesive mass with the ratio of 24 gram epoxy resin to 24 gram epoxy hardener, so the adhesive concentration was $13 \%$.

3. Sample 3 used $20 \%$ adhesive mass with the ratio of 32 gram epoxy resin to 32 gram epoxy hardener, so the adhesive concentration was $17 \%$.

4. Sample 4 used $25 \%$ adhesive mass with the ratio of 40 gram epoxy resin to 40 gram epoxy hardener, so the adhesive concentration was $20 \%$.
5. Sample 5 used $30 \%$ adhesive mass with the ratio of 48 gram epoxy resin to 48 gram epoxy hardener, so the adhesive concentration was $23 \%$.

The process of molding composite board used hot and cold pressing. Hot pressing was performed at $100^{\circ} \mathrm{C}$ with 10 $\mathrm{kgf} / \mathrm{cm}^{2}$ pressure for 1 hour. After hot pressing, cold pressing was performed for 48 hours. After pressing, conditioning was performed for 1 week so that composite board could adjust its temperature with the environment before testing.

The mechanical property test of composite boards was tensile strength test. The test referred to SNI 03-2105-2006. The tensile strength of composite board was obtained using equation:

$$
K_{r}=\frac{B}{A}
$$

Where:

$$
\begin{aligned}
K_{r} & =\text { tensile strength of composite board }\left(\mathrm{kgf} / \mathrm{cm}^{2}\right) \\
B & =\text { breaking load }(\mathrm{kgf}) \\
A & =\text { area of test sample }\left(\mathrm{cm}^{2}\right)
\end{aligned}
$$

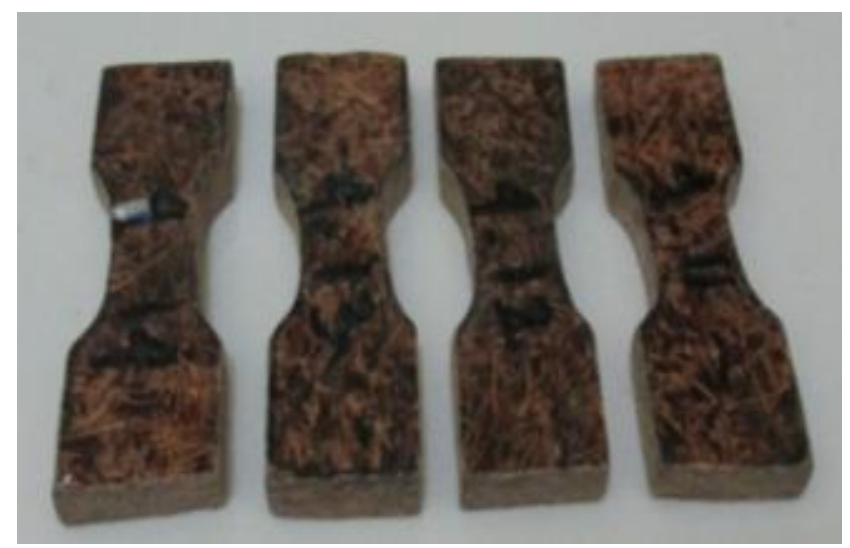

Fig. 3. Tensile Test Sample

\section{RESULT AND DISCUSSION}

The production of composite board made of sago pulp used 5 samples. The concentrations of adhesive were $9 \%$, $13 \%, 17 \%, 20 \%$ and $23 \%$.

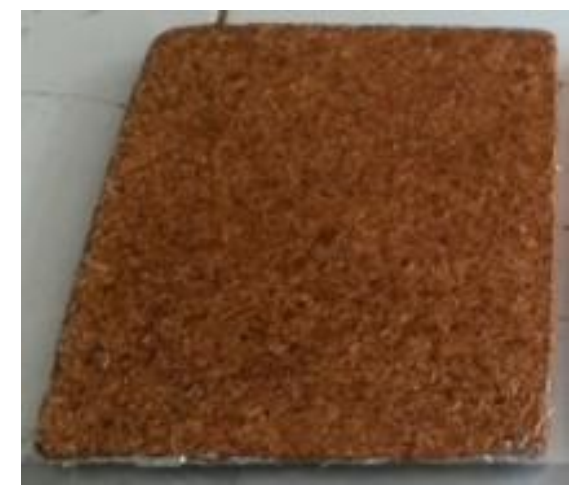

Fig. 4. Sago pulp composite board 
The tensile strength test of composite board was performed 3 times on each concentration of adhesive. The tests produced the following elastic modulus value and ultimate strength values :

TABLE I. AVERAGE Ultimate StRENGTH OF COMPOSITE BOARD

\begin{tabular}{|l|l|l|l|}
\hline No. & $\begin{array}{c}\text { Concentration } \\
\text { of Adhesive } \\
(\%)\end{array}$ & $\begin{array}{c}\text { Average Elastic } \\
\text { Modulus }\left(\mathbf{N} / \mathbf{m}^{2}\right)\end{array}$ & $\begin{array}{c}\text { Average Ultimate } \\
\text { Strength }\left(\mathbf{N} / \mathbf{m}^{2}\right)\end{array}$ \\
\hline 1. & 9 & $1,7 \times 10^{8}$ & $8 \times 10^{6}$ \\
\hline 2. & 13 & $9,3 \times 10^{7}$ & $8,6 \times 10^{6}$ \\
\hline 3. & 17 & $3 \times 10^{8}$ & $11 \times 10^{6}$ \\
\hline 4. & 20 & $3 \times 10^{8}$ & $10 \times 10^{6}$ \\
\hline 5. & 23 & $2 \times 10^{8}$ & $8,9 \times 10^{6}$ \\
\hline
\end{tabular}

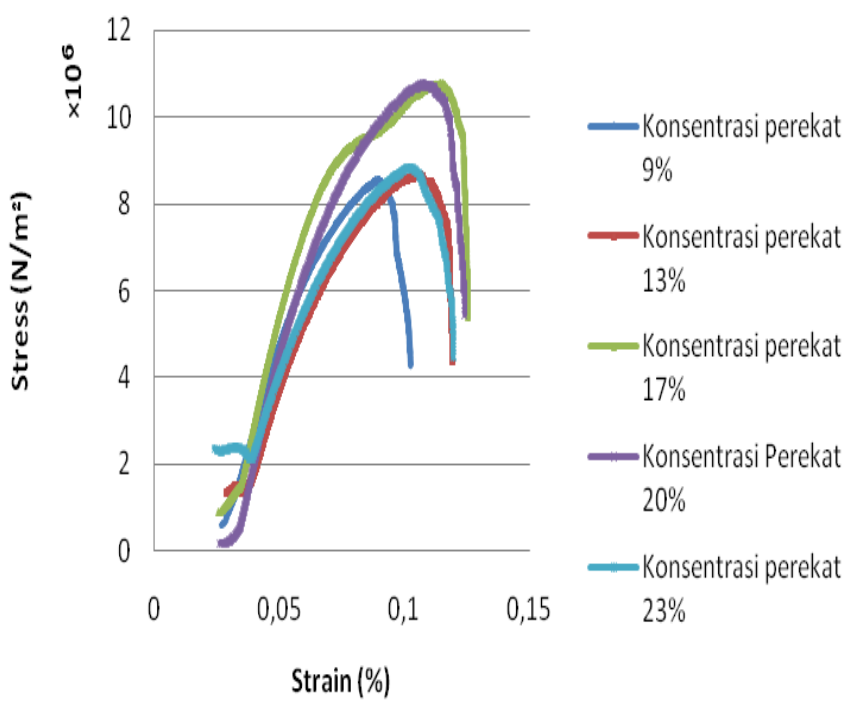

Fig. 5. Graph of Tensile Test Comparison

Every type of deformation on a unit is called stress. Stress is the strength of forces caused by pulling, squeezing or twisting. The result of deformation is called strain. When stress and strain are quite small, stress and strain will be direction proportional to each other, called elastic modulus [6]. Elastic modulus show value mesure of the resistance composite board before undergoing elastic deformation when given force.

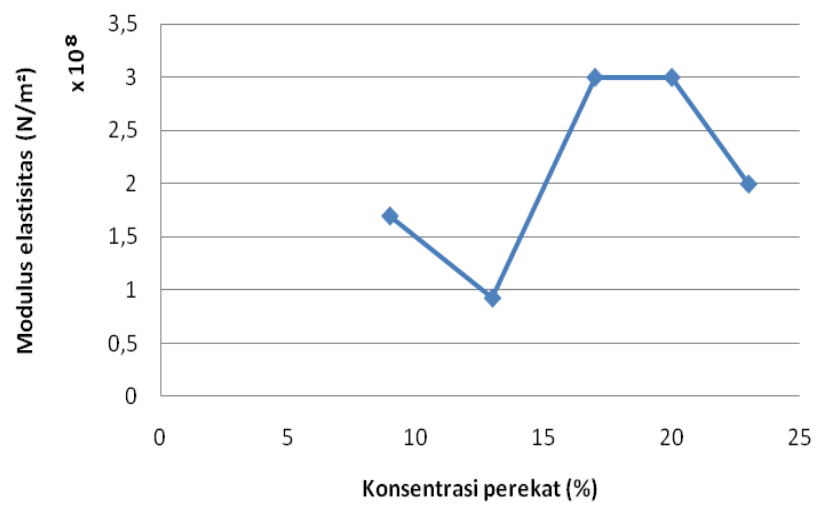

Fig. 6. Graph of Average Elastic Modulus of Composite Board
Elastic modulus was comparison between stress and strain when composite board was in elastic area. The lowest elastic modulus of sago pulp composite board was found in the sample with $13 \%$ concentration of adhesive with elastic modulus value of $9,3 \times 10^{7} \mathrm{~N} / \mathrm{m}^{2}$. Meanwhile, the highest elastic modulus was found in the sample with $20 \%$ concentration of adhesive with elastic modulus value of $3 \times$ $10^{8} \mathrm{~N} / \mathrm{m}^{2}$.

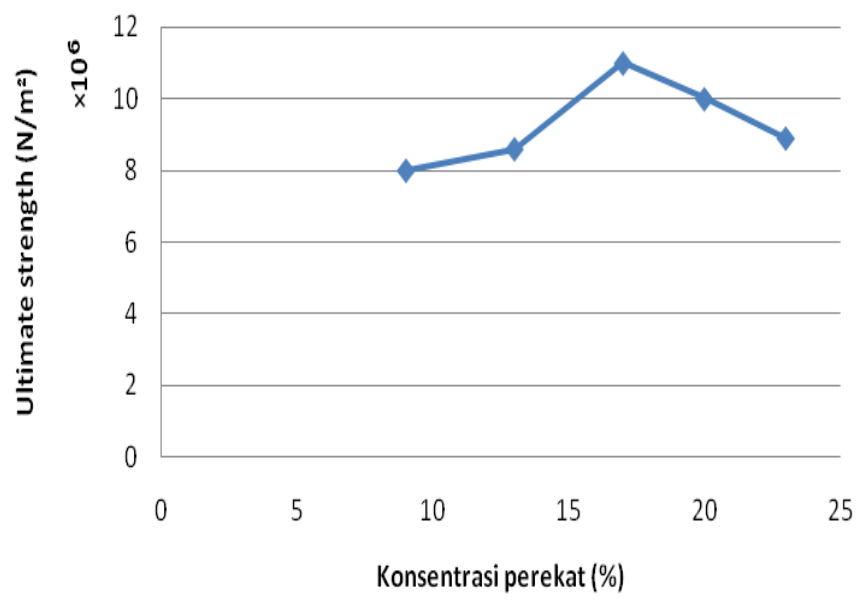

Fig. 7. Graph of Average Ultimate Strength of Composite board

Ultimate strength is maximum stress which can be borne by a material when pulled before the material breaks. The lowest ultimate strength in sago pulp composite boards was in the board with $9 \%$ concentration of adhesive with ultimate strength value of $8 \times 10^{6} \mathrm{~N} / \mathrm{m}^{2}$. Meanwhile, the highest ultimate strength was found in composite board with $17 \%$ concentration with ultimate strength value of $11 \times 10^{6} \mathrm{~N} / \mathrm{m}^{2}$. A previous study 'Production and Characterization of Picket Board Composite from Cacao Skin Waste' shows ultimate strength values ranging between $55,27 \times 10^{4} \mathrm{~N} / \mathrm{m}^{2}-115,15 \times$ $10^{4} \mathrm{~N} / \mathrm{m}^{2}$ [5]So the ultimate strength of sago pulp composite board was quite high.

Tensile strength is the resistance of the perpendicular pull of the composite board until the board breaks. The tensile strength of the composite board show the mixing of the adhesive, formation of material particles and pressing of the board [6]Length and diameter of the fiber is very influential in tensile strength and strain

\section{CONCLUSION}

Composite boards with concentrations of adhesive of $9 \%$, $13 \%, 17 \%, 20 \%, 23 \%$ and characterization of mechanical property of sago pulp composite board was performed. The tensile test of sago pulp composite board showed elastic modulus ranging between $9,3 \times 10^{7} \mathrm{~N} / \mathrm{m}^{2}-3 \times 10^{8} \mathrm{~N} / \mathrm{m}^{2}$. The ultimate strength ranged between $8 \times 10^{6} \mathrm{~N} / \mathrm{m}^{2}-11 \times 10^{6}$ $\mathrm{N} / \mathrm{m}^{2}$. The ultimate strength of sago pulp composite board was quite high. 


\section{ACKNOWLEDGMENT}

This article was written based on the research conducted by the support of Rector of Musamus University and the Dean of Teacher Training and Education Faculty of Musamus University, so the writers convey the big thank for the material and spiritual support.

\section{REFERENCE}

[1] P. Harsanto, Budidaya dan Pengolahan Sagu, Yogyakarta: Kanisius,
1986.

[2] S. Budiwiyanto, Joko, and Badriyah, "Processing Limbukyu as Supporting Material in Producing Java Furniture," Atl. Press, pp. 169$173,2017$.

[3] R.M. Rowell, R.A. Young, and J.K. Rowell, Paper and Composite from Agro-Based Resources. USA: CRC Lewis Publisher, Boca Raton, FL, 1996.

[4] J.G.F. Bowyer, R. Shmulsky, and Haygreen, Product and Wood Science, 4th ed. IOWA State Press A Blackwell, 2003.

[5] J. Panjaitan, Pembuatan dan Karakterisasi Komposit Papan Partikel dari Limbah Kulit Kakao, Bandung: ITB, 2013.

[6] Z. Sears, Fisika Universitas, Jakarta: Erlangga, 2002. 